\title{
Impact of the COVID-19 Outbreak on the Long-range Transport of Particulate PAHs in East Asia
}

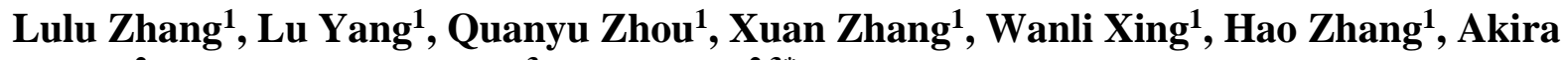 \\ Toriba $^{2}$, Kazuichi Hayakawa ${ }^{3}$, Ning Tang ${ }^{2,3 *}$ \\ ${ }^{1}$ Graduate School of Medical Sciences, Kanazawa University, Kakuma-machi, Kanazawa 920-1192, Japan \\ ${ }^{2}$ Institute of Medical, Pharmaceutical and Health Sciences, Kanazawa University, Kakuma-machi, Kanazawa 920-1192, \\ Japan \\ ${ }^{3}$ Institute of Nature and Environmental Technology, Kanazawa University, Kakuma-machi, Kanazawa 920-1192, Japan
}

\begin{abstract}
Particulate polycyclic aromatic hydrocarbons (PAHs) were continuously observed at Kanazawa University Wajima Air Monitoring Station (KUWAMS), a background site located in western Japan and downwind of mainland China that is constantly under the influence of polluted air masses originating from China. The observations showed that the concentration of particulate PAHs at KUWAMS sharply dropped to the lowest level $\left(62 \mathrm{pg} \mathrm{m}^{-3}\right)$ of the cold season in the last 5 years after the implementation of COVID-19 control measures in China. Despite the occasional dilution with clean air, the decrease in PAHs at KUWAMS reflected the reduction in emission intensity in China. Moreover, the PAH concentrations at KUWAMS in February, March, and April of 2020 compared with the same period in the previous year decreased by $52.6 \%, 36.6 \%$, and $36.7 \%$, respectively. These changes were consistent with the decline in $\mathrm{SO}_{2}$ and $\mathrm{NO}_{2}$ in northern China, which intensified during the control of COVID-19 and was slightly moderated after the resumption of work. In addition, there was little change in the composition of PAHs at KUWAMS before and during the COVID-19 outbreak and compared with previous years, which suggests a stable source composition. These findings emphasize the importance of decreased emission intensity in China for reducing long-range transport of PAHs and pollution levels in downwind areas.
\end{abstract}

Keywords: Polycyclic aromatic hydrocarbons; Air pollution; Background site; KUWAMS.

\section{INTRODUCTION}

Polycyclic aromatic hydrocarbons (PAHs) are an important component of atmospheric particulates that influence the hormonal impact of particulates and their carcinogenic and mutagenic potential (Durant et al., 1996; Zhang et al., 2016). PAHs primarily originate from the incomplete combustion of organic materials, such as petroleum, coal, and biomass, as well as the evaporation and escape of PAHs in raw materials and fuel (Lee et al., 1995; Yang et al., 1998; Lee et al., 2004; Chang et al., 2013). After entering the atmosphere, PAHs undergo gas-particle partitioning, transportation, conversion, and dry and wet deposition into the local environment of the receptor domain (Cheruiyot et al., 2015). Compared with low-molecular-weight PAHs, high-molecular-weight PAHs that with higher toxic potential tend to bind particles, especially those with fine size (Sheu et al., 1996; Lee et al., 2002;

\footnotetext{
* Corresponding author.

Tel.: +81-76-234-4455; Fax: +81-76-234-4455

E-mail address: n_tang@staff.kanazawa-u.ac.jp
}

Lin et al., 2008). Airborne particles carrying PAHs can participate in the short- and long-range transport of air masses (Zhang et al., 2020b). Although the physical and chemical behavior of PAHs during transport may lead to the loss of PAHs in particles, the enhanced health risks caused by PAHs transported to the recipient site cannot be ignored (Lee et al., 1995; Sheu et al., 1997; Zhang et al., 2020e).

Globally, China is a major consumer of energy. In 2018, China accounted for $24 \%$ of global energy consumption of which coal and oil accounted for $58 \%$ and $18.9 \%$, respectively (bp p.l.c., 2019; NBSC, 2019). As a result, the concentration of atmospheric PAHs in China is much higher than that of some Asian, European and American countries (Sanderson et al., 2004; Delhomme and Millet, 2012; Shen et al., 2013; Tang et al., 2017; Zhang et al., 2019a; Hayakawa et al., 2020), although strict air pollution control measures instituted by China have effectively improved air quality in recent years (Zheng et al., 2018; Zhang et al., 2019c).

In particular, in northern China, central heating routinely lasts up to five months per year (from November to March of the following year), and the span of unorganized coal heating lasts even longer. These activities not only increase the load of atmospheric PAHs in China but also worsen air 
pollution in downwind countries and regions (Pan et al., 2015; Inomata et al., 2017; Li et al., 2018). The observations over 15 years at Kanazawa University Wajima Air Monitoring Station (KUWAMS), a remote background site in Japan, provide hard evidence of the transport of pollutants (Tang et al., 2005; Yang et al., 2007; Tang et al., 2014, 2015; Zhang et al., 2020e). Driven by the East Asian monsoon system, polluted air masses in northern China can be transported to Japan with Northwest winds from November to May of the following year (the cold season); between June and October (the warm season), the airflow is driven by southerly winds from the North Pacific (Tang et al., 2015). Consequently, the concentration of particulate PAHs observed at KUWAMS shows regular seasonal changes (Fig. 1) (Tang et al., 2015; Zhang et al., 2020e), with increased PAHs in the cold season and decreased PAHs in the warm season. In addition, the mitigation of air pollution in response to control measures taken by China, for example, the interim control measures for the 2008 Beijing Olympic Games (BMEPB, 2008), the Air Pollution Prevention and Control Action Plan implemented from 2013 to 2017 (State Council, PRC, 2013), and the clean energy heating project launched in northern China since 2017 (NDRC, 2017), has been reflected in the long-term observations at KUWAMS (Tang et al., 2014, 2015; Zhang et al., 2020e). Although KUWAMS is sometimes affected by polluted air masses in Japan, the level of atmospheric PAHs in Japanese cities is two orders of magnitude lower than that in China (Morisaki et al., 2016). Moreover, the primary contributor to PAHs in Japan is motor vehicles (Hayakawa et al., 2018), while the long-term observations at KUWAMS suggest that the source of PAHs tallies with the mixed emission sources in China. Therefore, KUWAMS is clearly a sensitive receptor site for changes in air pollution on mainland China.

At the beginning of 2020, COVID-19 broke out in China and rapidly spread throughout the country. To limit the spread of the COVID-19 virus, Wuhan and other cities in Hubei Province announced lockdowns on January 23 and 24, 2020, respectively. Other provinces in China had started their emergency response systems by January 29. As a result, industrial, traffic, and social activities were largely suspended in China, effectively reducing the intensity of pollution emissions and air pollution levels (Wang et al., 2020; Xu et al., 2020; Zhang et al., 2020d). According to the data released by the Ministry of Ecology and Environment of the People's Republic of China (MEE, 2020a), $\mathrm{PM}_{10}, \mathrm{PM}_{2.5}, \mathrm{SO}_{2}$, and $\mathrm{NO}_{2}$ in 337 cities in China decreased by $30.0 \%, 27.3 \%$, $23.1 \%$ and $28.0 \%$, respectively, compared with the values for February of the previous year, and the decline was more significant than the other winter months. Therefore, the reduced pollution emissions in China during COVID-19 are expected to reduce the pollutants involved in long-range transportation and to mitigate air pollution in East Asia.

The purpose of this study was to document the impact of measures implemented in China to control the COVID-19 virus on the long-range transport of PAHs in East Asia. In this work, particulate PAHs were measured at KUWAMS and the partition of PAHs in the gas phase was estimated by models. Changes in particulate PAHs at KUWAMS during the 2020 cold season and during COVID-19 were investigated by comparison with the previous 15 years of observations. In addition, the driving factors were evaluated by estimating the airflow trajectory to KUWAMS during COVID-19 control measures and by analyzing changes in the composition of PAHs. The results of this study contribute to a better understanding of the transport and distribution of PAHs in the atmosphere of East Asia and provide an important basis for the improvement of air quality.

\section{METHODS}

\section{Air Particulate Sampling}

KUWAMS (Nisifutamata-machi, Wajima City, Ishikawa Prefecture, Japan; $37.4^{\circ} \mathrm{N}, 136.9^{\circ} \mathrm{E} ; 60 \mathrm{~m}$ above sea level) is located on the Noto Peninsula in western Japan (Fig. 2), $2.1 \mathrm{~km}$ from the coastline of the Sea of Japan. A detailed description of KUWAMS is provided elsewhere (Yang et al., 2007; Tang et al., 2014). The collection of total suspended

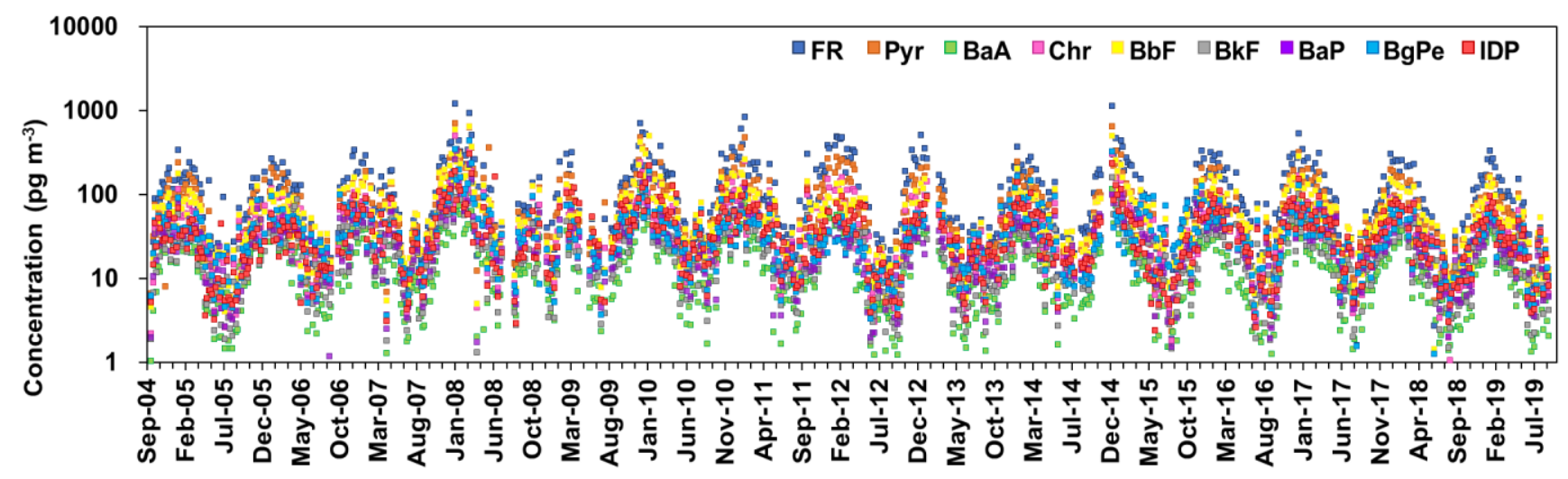

Fig. 1. Concentration profile of particulate polycyclic aromatic hydrocarbons (PAHs) at Kanazawa University Wajima Air Monitoring Station (KUWAMS) from Sep. 2004 to Aug. 2019 (Tang et al., 2015; Zhang et al., 2020e), showing an approximately sinusoidal trend. FR: fluoranthene; Pyr: pyrene; BaA: benz $[a]$ anthracene; Chr: chrysene; BbF: benzo[b]fluoranthene; BkF: benzo[k]fluoranthene; BaP: benzo[a]pyrene; $\mathrm{BgPe}$ : benzo[ghi]perylene; IDP: indeno[1,2,3$c d$ pyrene. 


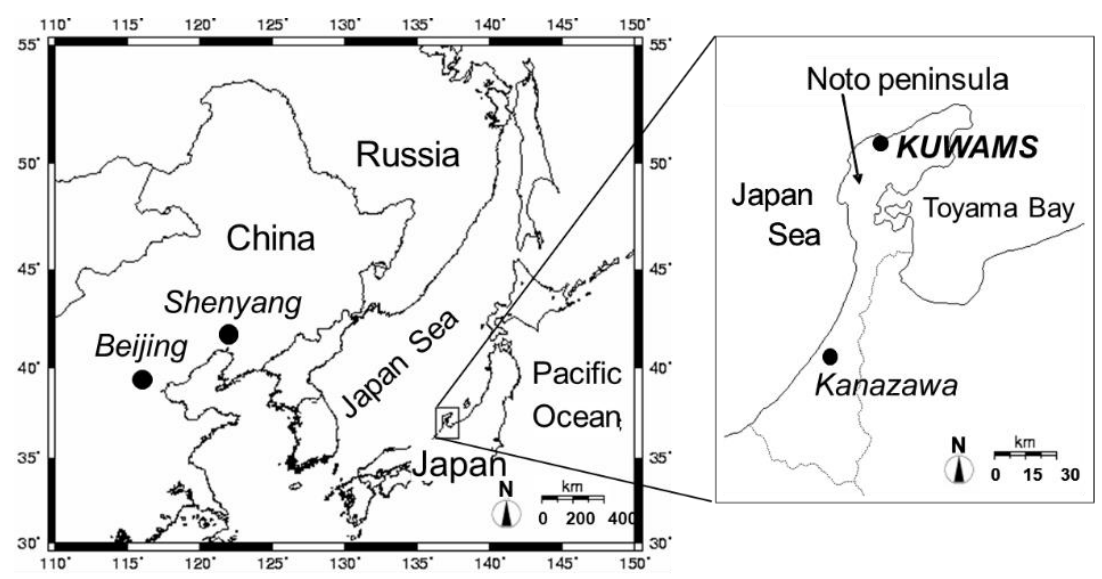

Fig. 2. Location of KUWAMS (Tang et al., 2014).

particulates (TSP) was performed using a high-volume air sampler (AH-600, Shibata Sci. Tech. Ltd., Saitama, Japan) on a quartz fiber filter ( 8 in. $\times 10$ in., 2500QAT-UP, Pallflex Products, Putnam, CT, USA) at a flow rate of $700 \mathrm{~L} \mathrm{~min}^{-1}$. The filter was replaced once a week from November 2, 2019, to April 25, 2020. Based on the prevailing period of the East Asian winter monsoon, this sampling period was defined as the cold season, which extended from November to May in the previous observations (Tang et al., 2015; Zhang et al., 2020e).

Before and after sampling, the filters were held in a desiccator with a constant temperature $\left(21.5 \pm 1.5^{\circ} \mathrm{C}\right)$ and humidity $(50 \pm 5 \%)$ and were protected from light for $24 \mathrm{~h}$. These filters were then weighed. The difference in the weight of each filter before and after sampling was used to calculate the TSP concentration. After gravimetric analysis, the sampled filters were stored at $-20^{\circ} \mathrm{C}$ until analysis. During sampling, the blank and sample filters were pretreated in the same way and delivered to KUWAMS to check the background variance. It was documented that no contamination occurred during storage, weighing, and transportation.

In addition, local meteorological conditions were automatically monitored by the weather Transmitter WXT530 during the sampling period. Meteorological parameters included temperature, relative humidity $(\mathrm{RH})$, pressure, wind speed, and rainfall. The details of meteorological monitoring are provided elsewhere (Zhang et al., 2020e).

\section{PAH Analysis}

Nine PAHs, fluoranthene (FR), pyrene (Pyr), benz $[a]$ anthracene (BaA), chrysene (Chr), benzo $[b]$ fluoranthene $(\mathrm{BbF})$, benzo $[k]$ fluoranthene $(\mathrm{BkF})$, benzo $[a]$ pyrene $(\mathrm{BaP})$, benzo $[$ ghi $]$ perylene $(\mathrm{BgPe})$, and indeno[1,2,3-cd]pyrene (IDP), were analyzed in each TSP sample. The U.S. EPA 610 PAH mix, including the nine target PAHs, was purchased from Dr. Ehrenstorfer GmbH (Augsburg, Germany). Two internal standards (Pyr- $d_{10}$ and BaP- $d_{12}$ ) were purchased from Wako Pure Chemicals (Osaka, Japan). All additional reagents were of analytical reagent grade.

The methods of pretreatment, analysis and quality control are consistent with those described in a previous study (Tang et al., 2005). Each filter was cut into small pieces and placed in a conical flask. After adding internal standards (Pyr- $d_{10}$, $0.14 \mathrm{mM}$ and BaP- $\left.d_{12}, 0.11 \mathrm{mM}\right)$, the compounds were extracted ultrasonically twice with benzene/ethanol $(3: 1, \mathrm{v} / \mathrm{v})$. The extract was washed successively with sodium hydroxide and sulfuric acid solutions, and twice with ultrapure water. After that, $100 \mu \mathrm{L}$ of dimethyl sulfoxide (DMSO) was added to the solution, which was then concentrated with rotation evaporator and dissolved to $1.0 \mathrm{~mL}$ in acetonitrile. After filtering the organic solution with an HLC-DISK membrane (pore size $0.45 \mu \mathrm{m}$, Kanto Chemical Co., Tokyo, Japan), an aliquot $(20 \mu \mathrm{L})$ of the solution was injected into a highperformance liquid chromatography (HPLC) system (LC-20A series, Shimadzu Inc., Kyoto, Japan) for quantitative determination.

The nine PAHs were determined by an HPLC coupled with fluorescence detection. A reversed-phase column (Inertsil ODS-P, 4.6 i.d. $\times 250$ mm, GL Sciences Inc., Tokyo, Japan) was employed for separating the PAH compounds. The mobile phase was an acetonitrile/water gradient with the flow rate at $1 \mathrm{~mL} \mathrm{~min}^{-1}$. The time program of the fluorescence detector was set to detect at the optimum excitation and emission wavelengths for each $\mathrm{PAH}$, which is consistent with the condition in the previous study (Tang et al., 2005). Internal standards were used to calibrate the recovery and quantification of each PAH. The recoveries ranged from 87 to $104 \%$. The limit of determination and quantification of each PAH was FR (70 and $240 \mathrm{pg} \mathrm{mL}^{-3}$ ), Pyr (6.3 and $21 \mathrm{pg} \mathrm{mL}^{-3}$ ), $\mathrm{BaA}\left(6.8\right.$ and $\left.23 \mathrm{pg} \mathrm{mL}^{-3}\right), \mathrm{Chr}\left(19\right.$ and $\left.63 \mathrm{pg} \mathrm{mL}^{-3}\right), \mathrm{BbF}$ (61 and $\left.200 \mathrm{pg} \mathrm{mL}^{-3}\right), \mathrm{BkF}$ (15 and $\left.49 \mathrm{pg} \mathrm{mL}^{-3}\right), \mathrm{BaP}(11$ and $\left.37 \mathrm{pg} \mathrm{mL}^{-3}\right), \mathrm{BgPe}\left(100\right.$ and $330 \mathrm{pg} \mathrm{mL}^{-3}$ ), and IDP (460 and $1550 \mathrm{pg} \mathrm{mL}^{-3}$ ), respectively.

\section{Data Analysis}

Statistics were performed using SPSS version 25.0 (IBM Co., Armonk, NY, US). Differences in the concentrations of TSP and PAHs between this study and previous observations were evaluated via a $t$-test. A $p$-value of less than 0.05 indicated that the results were statistically significant.

The backward trajectory model (HYSPLIT-WEB, Internetbased, the NOAA Air Resources Laboratory, https://www.re ady.noaa.gov/HYSPLIT_traj.php) is widely used in environmental analysis to track air masses (Yang et al., 2019; 
Zhang et al., 2019b). In this work, the trajectories of airflow arriving at KUWAMS during the sampling periods (between January 18 and 25, between January 25 and February 1, and between February 1 and 8, 2020) were estimated by using the HYSPLIT model and the GDAS one-degree archive. The start time was set to 0:00 UTC on January 18, January 25, and February 1, 2020, which corresponds to the local time (9:00 a.m.) when the filter was replaced. A new trajectory was calculated every $24 \mathrm{~h}$. Based on the previous reports (Tang et al., 2015; Zhang et al., 2020e), the backtracking time was set at $72 \mathrm{~h}$, and the initial height was set at $1000 \mathrm{~m}$ above ground level.

\section{Gas-particle Partitioning}

The concentration of PAHs in the gas phase was estimated by the gas-particle partition model. Firstly, the partition coefficient $K_{\mathrm{p}}$ (unit: $\mathrm{m}^{3} \mu \mathrm{g}^{-1}$ ) for each PAH between TSP and gas phase was calculated by Eq. (1), which is based on the adsorption of PAHs by particles (Pankow, 1987) and the absorption of PAHs by organic matter in the particle (Pankow, 1994, 1998). This model is widely used for evaluating the gas-particle partitioning of semi-volatile organic compounds in the atmosphere (Kishida et al., 2011; Huang et al., 2014; Liu et al., 2014).

$\lg K_{p}=\lg K_{O A}+\lg f_{\text {om }}-11.91$

where $K_{\mathrm{OA}}$ is the octanol/air partition coefficient of each PAH, $\left(\mathrm{g} \mathrm{mL}^{-1}\right)_{\text {octanol }}\left(\mathrm{g} \mathrm{mL}^{-1}\right)^{-1}$ air $; f_{\text {om }}$ is the mass fraction of organic matter in TSP. The $K_{\mathrm{OA}}$ used in this study refers to the report of Odabasi et al. (2006); the $f_{\text {om }}$ was estimated to be 0.1 based on previous measurements at KUWAMS (Zhang et al., 2020e). The concentration of PAHs in the gas phase was then calculated by Eq. (2) (Yamazaki et al., 1982).

$K_{p}=\frac{C_{p} / C_{T S P}}{C_{g}}$

where $C_{\mathrm{p}}$ and $C_{\mathrm{g}}$ are the concentration of each PAH in TSP and gas phase, respectively, $\mathrm{pg} \mathrm{m}^{-3}$; and $C_{\mathrm{TSP}}$ is the concentration of TSP, $\mu \mathrm{g} \mathrm{m}^{-3}$.

\section{RESULTS AND DISCUSSION}

\section{Overview of TSP and PAHs during the Cold Season}

The concentration of TSP collected at KUWAMS during the sampling period is shown in Table 1. For the purpose of comparison, Table 1 summarizes the data from previous long-term observations at KUWAMS, including those during the cold season from 2004 to 2014 (Campaign 1; Tang et al., 2015) and from 2014 to 2019 (Campaign 2; Zhang et al., 2020e). The average TSP concentration \pm standard deviation at KUWAMS during the present sampling period was $9.7 \pm$ $2.8 \mu \mathrm{g} \mathrm{m}^{-3}$, which was significantly lower than that during Campaign $1\left(21 \pm 14 \mathrm{pg} \mathrm{m}^{-3} ; p<0.001\right)$ and Campaign $2(20 \pm$

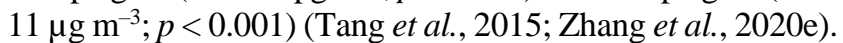

Table 2 presents the gas-particle partitioning of PAHs in the atmosphere at KUWAMS during the sampling period calculated by models. The sum of the concentration of PAHs in the TSP and gas phase at KUWAMS was estimated at $25100 \pm 11000 \mathrm{pg} \mathrm{m}^{-3}$ with around $1.1 \%$ of PAHs bound with TSP. These results indicate that the concentration of PAHs transported from mainland China during the sampling period was much higher than the concentration of PAHs in the TSP detected in this study. In addition, 4-ring PAHs (FR, $\mathrm{Pyr}, \mathrm{BaA}$, and Chr) mostly existed in the gas phase, while 5and 6-ring PAHs were mostly bound with TSP. This gasparticle partition pattern is consistent with the observations of many studies (Ohura et al., 2004; Kishida et al., 2011; Huang et al., 2014; Liu et al., 2014). However, because of the influence of environmental conditions and the nature of particles, using the documented parameters to estimate $K_{\mathrm{p}}$ can lead to an uncertainty of up to $95 \%$ (Yamazaki et al., 1982; Araki et al., 2009; Salthammer and Schripp, 2015). Considering the high uncertainty of the calculated PAH concentrations in the gas phase, the following sections focus on particulate PAHs for further discussion. On the other hand, compared with model calculations, the measured results have higher reliability (Salthammer and Schripp, 2015). Therefore, the monitoring of gas-phase PAHs will be considered in our future research to characterize PAHs more comprehensively.

Table 1. Mean concentration \pm standard variation of total suspended particulates (TSP) and PAHs at KUWAMS in the cold season from 2004 to 2020.

\begin{tabular}{llll}
\hline Sampling period & $\begin{array}{l}\text { Campaign } 1^{a} \\
2004-2014\end{array}$ & $\begin{array}{l}\text { Campaign }^{b} \\
2014-2019\end{array}$ & $2019-2020$ \\
\hline${\text { TSP }\left(\mu \mathrm{g} \mathrm{m}^{-3}\right)}^{b}$ & $21 \pm 14$ & $20 \pm 11$ & $9.7 \pm 2.8$ \\
$\mathrm{PAHs}^{d}\left(\mathrm{pg} \mathrm{m}^{-3}\right)$ & $670 \pm 360$ & $550 \pm 300$ & $270 \pm 160$ \\
$\mathrm{FR}$ & $170 \pm 110$ & $150 \pm 92$ & $71 \pm 40$ \\
$\mathrm{Pyr}$ & $110 \pm 71$ & $94 \pm 57$ & $49 \pm 27$ \\
$\mathrm{BaA}$ & $24 \pm 15$ & $21 \pm 13$ & $11 \pm 7$ \\
$\mathrm{Chr}$ & $62 \pm 36$ & $49 \pm 25$ & $24 \pm 14$ \\
$\mathrm{BbF}$ & $85 \pm 54$ & $80 \pm 43$ & $37 \pm 23$ \\
$\mathrm{BkF}$ & $31 \pm 19$ & $29 \pm 15$ & $13 \pm 8$ \\
$\mathrm{BaP}$ & $39 \pm 28$ & $37 \pm 19$ & $17 \pm 10$ \\
$\mathrm{BgPe}$ & $48 \pm 30$ & $41 \pm 23$ & $23 \pm 13$ \\
$\mathrm{IDP}$ & $49 \pm 29$ & $45 \pm 24$ & $23 \pm 13$ \\
\hline
\end{tabular}

\footnotetext{
${ }^{a}$ Tang et al., 2015; The number of samples $n=280 .{ }^{b}$ Zhang et al., 2020e; $n=94 .{ }^{c} n=27 .{ }^{d}$ Total PAHs.
} 
Table 2. Gas-particle partitioning of PAHs at KUWAMS during the sampling period calculated by models.

\begin{tabular}{llll}
\hline PAH & $C_{\mathrm{g}}{ }^{a}$ & $C_{\mathrm{g}}+C_{\mathrm{p}}{ }^{b}$ & $\mathrm{C}_{\mathrm{p}} /\left(C_{\mathrm{g}}+C_{\mathrm{p}}\right)$ \\
\hline LPAHs & $24900 \pm 11000$ & $25100 \pm 11000$ & $1.1 \% \pm 0.29 \%$ \\
$\mathrm{FR}$ & $15400 \pm 6800$ & $15500 \pm 6900$ & $0.45 \% \pm 0.12 \%$ \\
$\mathrm{Pyr}$ & $9200 \pm 3900$ & $9300 \pm 3900$ & $0.53 \% \pm 0.14 \%$ \\
$\mathrm{BaA}$ & $49 \pm 25$ & $60 \pm 31$ & $18 \% \pm 4.3 \%$ \\
$\mathrm{Chr}$ & $100 \pm 44$ & $120 \pm 57$ & $19 \% \pm 4.5 \%$ \\
$\mathrm{BbF}$ & $11 \pm 5.1$ & $48 \pm 28$ & $76 \% \pm 5.4 \%$ \\
$\mathrm{BkF}$ & $3.6 \pm 1.7$ & $17 \pm 9.6$ & $77 \% \pm 5.1 \%$ \\
$\mathrm{BaP}$ & $2.8 \pm 1.3$ & $19 \pm 11$ & $85 \% \pm 3.8 \%$ \\
$\mathrm{BgPe}$ & $0.32 \pm 0.14$ & $23 \pm 13$ & $98 \% \pm 0.45 \%$ \\
$\mathrm{IDP}$ & $0.42 \pm 0.19$ & $23 \pm 13$ & $98 \% \pm 0.59 \%$ \\
\hline
\end{tabular}

${ }^{a}$ The concentration of each PAH in the gas phase, $\mathrm{pg} \mathrm{m}^{-3} \cdot{ }^{b}$ The sum of the concentration of each PAH in the TSP and gas phase, $\mathrm{pg} \mathrm{m}^{-3}$.

As shown in Table 1, the average level of PAHs in the TSP during the present sampling period $\left(270 \pm 160 \mathrm{pg} \mathrm{m}^{-3}\right)$ was significantly lower than that during Campaign $1(670 \pm$ $\left.360 \mathrm{pg} \mathrm{m}^{-3} ; p<0.001\right)$ and Campaign $2\left(550 \pm 300 \mathrm{pg} \mathrm{m}^{-3}\right.$; $p<0.001$ ) (Tang et al., 2015; Zhang et al., 2020e), which was similar to the variation of TSP. As mentioned above, the Chinese government has been committed to controlling air pollution in recent years and has effectively improved air quality nationwide (Zheng et al., 2018). Therefore, the downward trend of TSP and PAHs at KUWAMS from Campaign 1 to Campaign 2 has been attributed to the reduction of pollutants transported from the Chinese mainland (Zhang et al., 2020e). This is also considered to be an important reason for the lower concentrations of TSP and PAHs during the sampling period in this study.

After the input of air pollutants into the atmosphere, the development of air pollution will be influenced by local meteorological conditions. Unfavorable meteorological conditions such as light air, calm winds, and high RH can lead to the accumulation of pollutants and heavy pollution. In contrast, an improvement in meteorological conditions will facilitate the diffusion of local pollutants (Zhang et al., 2015; Zhong et al., 2018). Based on 15 years of observations at KUWAMS during Campaign 1 and Campaign 2, the particulate PAHs were significantly negatively correlated with temperature during the cold season, but no significant correlation was found between PAHs and wind speed or RH (Tang et al., 2015; Zhang et al., 2020e). Due to the semivolatility of PAHs, the increase in temperature promotes the transition of particulate PAHs into the gas phase, whereas low temperature is conducive to the accumulation of PAHs into particles (Araki et al., 2009). Based on the comparison in Table 3, the monthly meteorological conditions at KUWAMS during the present sampling period were comparable to those during Campaign 2 (Zhang et al., 2020e). This finding suggests that the effects of local meteorological conditions on TSP and PAHs during the two sampling periods were similar. Moreover, long-range transport was the primary factor affecting the variation in TSP and PAHs at KUWAMS. On the other hand, since temperature is an important factor affecting the gas-particle partitioning of PAHs, the relatively stable monthly temperature at KUWAMS (Table 3) indicates that the gas-particle partition pattern of
PAHs changed a little in the past long-term observation. These results emphasize the comparability between the concentration of particulate PAHs during the present sampling period and the previous campaign.

PAHs are typically released from pollution sources as a mixture, and the combustion temperature and fuel type play an important role in the composition of the resulting PAHs (Tang et al., 2005; Ravindra et al., 2008; Phoungthong et al., 2017). Thus, the molar ratio of characteristic PAHs is widely used to identify their major sources (Tang et al., 2017; Xing et al., 2020). Table 4 compares the characteristic ratios of PAHs at KUWAMS in this study with previous observations. The ratios of the five PAH pairs during the present sampling period were consistent with those during Campaign 1 and Campaign 2 (Tang et al., 2015; Zhang et al., 2020e). Due to the lack of emission sources near KUWAMS and the relatively stable meteorological conditions, it is inferred that the composition of the source of PAHs has not changed substantially. The ratios of $[\mathrm{FR}] /([\mathrm{Pyr}]+[\mathrm{FR}]),[\mathrm{BaA}] /([\mathrm{Chr}]$ $+[\mathrm{BaA}])$ and $[\mathrm{IDP}] /([\mathrm{BgPe}]+[\mathrm{IDP}])($ Table 4$)$ were closer to the range indicating vehicle emissions (Sicre et al., 1987; Rogge et al., 1993; Tang et al., 2005), whereas the ratios of $[\mathrm{BbF}] /([\mathrm{BbF}]+[\mathrm{BkF}])$ and $[\mathrm{BaP}] /([\mathrm{BaP}]+[\mathrm{BgPe}])$ indicated an origin of coal combustion (Daisey et al., 1979; Masclet et al., 1987; Huang et al., 2014). These results are consistent with previous observations that particulate PAHs at KUWAMS are jointly affected by vehicle exhaust and coal combustion (Tang et al., 2015; Zhang et al., 2020e). Although a large fraction of 4-ring PAHs was distributed in the gas phase (Table 2), the characteristic ratios obtained after considering the gas-phase concentration were consistent with those of particulate PAHs (Table 4). This result emphasizes the stable source of atmospheric PAHs at KUWAMS.

\section{Changes in TSP and PAHs during COVID-19}

Fig. 3 shows the weekly variation in PAHs and TSP at KUWAMS during the cold season over the last 5 years. The concentration of TSP (represented by hollow squares) showed a similar trend in each cold season from 2015 to 2019 (Figs. 3(a)-3(d)). The TSP concentration was approximately $20 \mu \mathrm{g} \mathrm{m}^{-3}$ between November and February of the following year. The TSP then rose to a relatively high level until the end of April, which can be attributed to the frequent invasion 
Table 3. Comparison of monthly meteorological conditions (mean \pm standard variation) at KUWAMS in this study and during Campaign 2 (Zhang et al., 2020e).

\begin{tabular}{lllllll}
\hline Month & & $\mathrm{T}^{a}\left({ }^{\circ} \mathrm{C}\right)$ & $\mathrm{RH}^{b}(\%)$ & Press $(\mathrm{hPa})$ & $\mathrm{WS}^{c}\left(\mathrm{~m} \mathrm{~s}^{-1}\right)$ & $\mathrm{Rain}^{d}(\mathrm{~mm})$ \\
\hline Nov. & This study & $9.78 \pm 2.40$ & $76.3 \pm 6.63$ & $1010 \pm 5.90$ & $0.98 \pm 0.28$ & $0.25 \pm 0.42$ \\
& Campaign 2 & $9.77 \pm 2.80$ & $80.6 \pm 5.00$ & $1010 \pm 3.81$ & $0.95 \pm 0.20$ & $0.27 \pm 0.38$ \\
Dec. & This study & $6.74 \pm 2.26$ & $76.4 \pm 6.91$ & $1010 \pm 5.22$ & $1.04 \pm 0.23$ & $0.19 \pm 0.26$ \\
& Campaign 2 & $4.78 \pm 2.79$ & $80.1 \pm 6.85$ & $1010 \pm 5.49$ & $1.06 \pm 0.26$ & $0.31 \pm 0.35$ \\
Jan. & This study & $5.12 \pm 1.95$ & $77.9 \pm 6.82$ & $1010 \pm 7.52$ & $1.01 \pm 0.30$ & $0.27 \pm 0.26$ \\
& Campaign 2 & $3.44 \pm 2.14$ & $75.1 \pm 7.66$ & $1010 \pm 5.19$ & $1.09 \pm 0.29$ & $0.17 \pm 0.30$ \\
Feb. & This study & $5.11 \pm 2.77$ & $76.3 \pm 5.51$ & $1010 \pm 6.12$ & $1.06 \pm 0.26$ & $0.22 \pm 0.33$ \\
& Campaign 2 & $4.96 \pm 2.14$ & $73.7 \pm 7.56$ & $1010 \pm 5.51$ & $1.08 \pm 0.25$ & $0.15 \pm 0.27$ \\
Mar. & This study & $7.13 \pm 2.60$ & $69.7 \pm 6.68$ & $1010 \pm 5.87$ & $1.12 \pm 0.24$ & $0.16 \pm 0.33$ \\
& Campaign 2 & $6.18 \pm 2.66$ & $74.7 \pm 6.95$ & $1010 \pm 5.53$ & $0.99 \pm 0.20$ & $0.23 \pm 0.48$ \\
Apr. & This study & $9.40 \pm 2.09$ & $69.1 \pm 7.66$ & $1010 \pm 5.09$ & $1.10 \pm 0.26$ & $0.14 \pm 0.24$ \\
& Campaign 2 & $11.8 \pm 3.36$ & $74.8 \pm 8.47$ & $1010 \pm 5.37$ & $1.01 \pm 0.24$ & $0.17 \pm 0.34$ \\
\hline
\end{tabular}

${ }^{a}$ Temperature. ${ }^{b}$ Relative Humidity. ${ }^{c}$ Wind Speed. ${ }^{d}$ Monthly rainfall.

Table 4. Characteristic ratios of PAH pairs at KUWAMS in the cold season from 2004 to 2020 and the range indicating different sources.

\begin{tabular}{llllll}
\hline \multirow{2}{*}{ Ratio } & {$[\mathrm{FR}] /([\mathrm{Pyr}]+$} & {$[\mathrm{BaA}] /([\mathrm{Chr}]+$} & {$[\mathrm{BbF}] /([\mathrm{BbF}]+$} & {$[\mathrm{BaP}] /([\mathrm{BaP}]+$} & {$[\mathrm{IDP}] /([\mathrm{BgPe}]+$} \\
& $[\mathrm{FR}])$ & $[\mathrm{BaA}])$ & $[\mathrm{BkF}])$ & $[\mathrm{BgPe}])$ & 0.44 \\
\hline Campaign 1 & $0.59^{a}$ & 0.28 & 0.74 & 0.45 & 0.50 \\
Campaign 2 & $0.61^{b}$ & 0.29 & 0.73 & $0.42 \pm 0.02$ & $0.52 \pm 0.02$ \\
This study & $0.58 \pm 0.02^{c}$ & $0.32 \pm 0.02$ & $0.74 \pm 0.01$ & $0.46 \pm 0.02$ & $0.50 \pm 0.02$ \\
This study & $0.62 \pm 0.02^{d}$ & $0.32 \pm 0.02$ & $0.74 \pm 0.01$ & $0.23-0.28^{h}$ & $0.35-0.7^{i}$ \\
Vehicle emission & $0.6-0.7^{e}$ & $0.36^{f}$ & $0.52-0.60^{g}$ & $0.47-0.86^{k}$ & $0.14-0.33^{f, j}$ \\
Coal combustion & $0.36-0.53^{f, j}$ & $0.5^{f}$ & $0.78-0.95^{h, j}$ & 0.47
\end{tabular}

${ }^{a}$ Median $(n=280) .{ }^{b}$ Mean $(n=94) .{ }^{c}$ Mean \pm standard variation $(n=27) .{ }^{d}$ The ratio was calculated based on the sum of the concentration of each PAH in the TSP and gas phase. ${ }^{e}$ Sicre et al., 1987. ${ }^{f}$ Tang et al., 2005. ${ }^{g}$ Dickhut et al., 2000.

${ }^{h}$ Masclet et al., 1987. ${ }^{i}$ Rogge et al., 1993. ${ }^{j}$ Huang et al., 2014. ${ }^{k}$ Daisey et al., 1979.

of Asian dust (Yang et al., 2007; Zhang et al., 2020c). In contrast to the trend in TSP, the concentration of PAHs (represented by solid circles) between November and February was higher than that between March and April (Figs. 3(a)-3(d)). This trend was essentially coincident with the central heating period in northern China as mentioned previously. After the central heating period, the levels of PAHs at KUWAMS decreased, and the occasional increase in PAHs might be associated with the presence of unorganized coal burning in rural areas (MEE, 2020b).

As shown in Fig. 3(e), the local TSP concentration has remained below $16 \mu \mathrm{g} \mathrm{m}^{-3}$ from November 2019 to April 2020. This is related to the absence of Asian dust at KUWAMS during this period (JMA, 2020). Impressively, due to the implementation of strategies against COVID-19 in China from January 23, 2020, the concentration of PAHs stabilized from late January to April of 2020 (Fig. 3(e)) at a lower level than that in the previous years (Figs. 3(a)-3(d)). To better understand this trend, the year to year changes in the concentrations of TSP and PAHs at KUWAMS were calculated (Table 5) and compared with those of air pollutants in the representative region of northern China, the Beijing-Tianjin-Hebei Metropolitan Region (BTH Metropolis) (MEE, 2020a). In comparison with the previous years, there was a relative increase in $\mathrm{PM}_{2.5}$ in December and January. But in subsequent months, the $\mathrm{PM}_{10}, \mathrm{PM}_{2.5}, \mathrm{SO}_{2}$, and $\mathrm{NO}_{2}$ in the BTH Metropolis showed decreases in each month with the largest decline in February, particularly $\mathrm{SO}_{2}$ and $\mathrm{NO}_{2}$, which are primary pollutants indicative of coal combustion and vehicle exhaust, respectively. These substantial reductions reflect the widespread suspension of industrial and traffic activities in China since the implementation of control measures related to the COVID-19 pandemic (Wang et al., 2020). As the COVID-19 pandemic has improved in China, the provinces outside Hubei have released strategies for a gradual return to work after February 10 (Zhang et al., 2020d). To avoid a recurrence of the pandemic, industrial production and traffic flow have been resumed at a slower pace. As a result, the decrease in air pollutants in the BTH Metropolis was moderated in March and April (MEE, 2020b); as shown in Table 5, the concentration of PAHs at KUWAMS decreased by $52.6 \%, 36.6 \%$, and $36.7 \%$ in a year to year comparison in February, March, and April, respectively. This trend corresponded to the changes in $\mathrm{SO}_{2}$ and $\mathrm{NO}_{2}$ in the BTH Metropolis, which highlights the direct effect of the reduction in industrial and traffic activities in northern China on the PAH level at KUWAMS.

It is worth noting that during the Chinese Spring Festival (a week-long holiday), the intensity of industrial emissions weakened (Tang et al., 2020). Although the sampling week at KUWAMS did not perfectly correspond to the Chinese Spring Festival (indicated by a gray rectangle in Fig. 3), the 

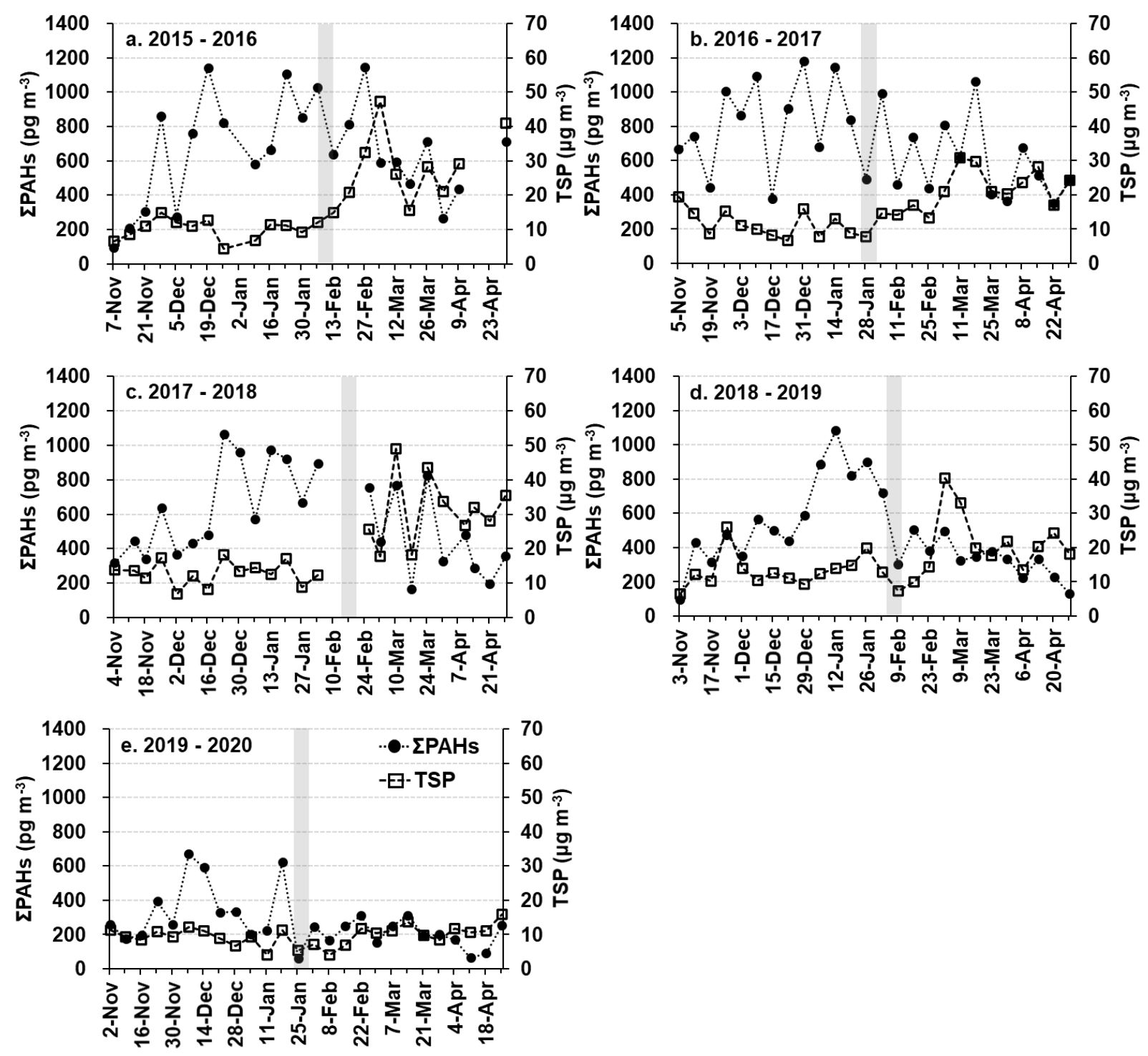

Fig. 3. Weekly variation of $\Sigma$ PAHs and TSP at KUWAMS in the cold season from 2015 to 2020 . The solid circle represents the concentration of $\Sigma$ PAHs. The hollow square represents the concentration of TSP. The gray rectangle represents the week of the Chinese Spring Festival. The data for 2015 to 2019 were collected from Zhang et al. (2020e).

Table 5. Year-on-year comparison of air pollutants in KUWAMS and Beijing-Tianjin-Hebei Metropolitan Region (BTH Metropolis) in the cold season from 2019 to 2020.

\begin{tabular}{|c|c|c|c|c|c|c|}
\hline Site / region & \multicolumn{2}{|c|}{ KUWAMS } & \multicolumn{4}{|c|}{ BTH Metropolis $^{a}$} \\
\hline Pollutants & इPAHs & TSP & $\mathrm{PM}_{10}$ & $\mathrm{PM}_{2.5}$ & $\mathrm{SO}_{2}$ & $\mathrm{NO}_{2}$ \\
\hline Nov. 2019 & $-22.5 \%^{b}$ & $-28.0 \%$ & $-10.4 \%$ & $-25.9 \%$ & $-20.0 \%$ & $-7.1 \%$ \\
\hline Dec. 2019 & $-1.6 \%$ & $-15.5 \%$ & $-16.4 \%$ & $1.2 \%$ & $-36.0 \%$ & $-5.5 \%$ \\
\hline Jan. 2020 & $-69.9 \%$ & $-50.6 \%$ & $-10.2 \%$ & $10.2 \%$ & $-36.7 \%$ & $-19.4 \%$ \\
\hline Feb. 2020 & $-52.6 \%$ & $-27.7 \%$ & $-45.7 \%$ & $-42.6 \%$ & $-40.0 \%$ & $-41.5 \%$ \\
\hline Mar. 2020 & $-36.6 \%$ & $-59.4 \%$ & $-24.1 \%$ & $-16.7 \%$ & $-25.0 \%$ & $-17.5 \%$ \\
\hline Apr. 2020 & $-36.7 \%$ & $-35.2 \%$ & $-17.8 \%$ & $-25.0 \%$ & $-7.1 \%$ & $-5.7 \%$ \\
\hline
\end{tabular}

${ }^{a}$ Monthly report for national air quality (MEE, 2020a). ${ }^{b}$ The year-on-year change was calculated by $100 \% \times($ present monthly mean - previous monthly mean)/previous monthly mean; for example, present: Nov. 2020, previous: Nov. 2019.

concentration of PAHs showed a decrease during the corresponding periods such as the samplings from February 13 to 20 in 2016, from January 28 to February 4 in 2017, and from February 9 to 16 in 2019. In 2020, the Chinese Spring Festival coincided with the period of COVID-19 control, leading to the concentration of PAHs at KUWAMS between 
January 25 and February 1 (Fig. 3(e)) falling to the lowest level $\left(62 \mathrm{pg} \mathrm{m}^{-3}\right)$ of the cold seasons from 2015 to 2020. This could explain the dramatic decline in the relative PAHs and TSP at KUWAMS in January 2020 (Table 5).

\section{Characteristics of PAHs from January 25 to February 1}

The week of overlap between the 2020 Chinese Spring Festival and the COVID-19 control period was identified as a period of particular interest and corresponded to the sampling week between January 25 and February 1 at KUWAMS. The trajectory of the airflow arriving at KUWAMS in the week before (W 1), during (W 2) and after (W 3) this period was estimated using the HYSPLIT model. As shown in Fig. 4, the airflow arriving at KUWAMS originated from or passed through northern China in W 1, when industrial and traffic activities in China continued as usual. The Northwest wind facilitated the transport of polluted air masses from northern China to KUWAMS, resulting in a relatively high PAH level $\left(620 \mathrm{pg} \mathrm{m}^{-3}\right)$ at KUWAMS. In W 2, the airflow carrying pollutants over northern China arrived at KUWAMS on January 25, 26, and 27, during which time the intensity of industrial and traffic pollution on the Chinese mainland declined (Wang et al., 2020; Xu et al., 2020). Moreover, the airflow arriving at KUWAMS between January 28 and February 1 originated from the Okhotsk Sea and the Philippine Sea on the North and South sides of Japan, respectively. Pollutants from other Japanese cities might have been transported to KUWAMS with the airflow in the lower atmosphere. However, the level of PAH pollution in Japan is much lower than that in China (Tang et al., 2013; Hayakawa et al., 2018; Zhang et al., 2020a). Therefore, the sharp decrease in PAH concentration to $62 \mathrm{pg} \mathrm{m}^{-3}$ in W 2 was attributed to the reduced input of pollutants reaching KUWAMS and the dilution with cleaner air. In W 3, the airflow largely returned to the control of the East Asian monsoon, where industrial production and traffic flow in northern China had not yet to resume. Consequently, the concentration of PAHs $\left(250 \mathrm{pg} \mathrm{m}^{-3}\right)$ at KUWAMS rebounded slightly but was still lower than the level in W 1.

Fig. 5 compares the composition of particulate PAHs in $\mathrm{W} 1$, W 2, and W 3 in 2020 with the same period in previous years, i.e., the week before (W 1), during (W 2) and after (W 3) the Chinese Spring Festival from 2016 to 2019. The data for 2018 were not available due to a sampler failure and were not included in the comparison. The composition of PAHs at KUWAMS remained stable around the Chinese Spring Festival from 2016 to 2020. In the sampling weeks in Fig. 5, the PAHs were dominated by 4-ring homologs (FR, Pyr, $\mathrm{BaA}$ and $\mathrm{Chr}$ ), which accounted for $54.7-62.6 \%$ of the total, followed by 5-ring $(\mathrm{BbF}, \mathrm{BkF}$ and $\mathrm{BaP})$ and 6-ring homologs (BgPe and IDP), which accounted for $23.3-26.3 \%$ and $14.1-$ $20.1 \%$, respectively. This result suggests that the reduced emission intensity in China had little effect on the composition of PAHs at KUWAMS, which supports the conclusion in section 3.1 that the main sources of PAHs did not change substantially. These findings are consistent with the assessment of the effectiveness of pollution control policies adopted in China, i.e., that the strengthening of emission standards has contributed substantially to the improvement in air quality, whereas the effect of energy structure adjustments was nonsignificant (Zhang et al., 2019c).

\section{CONCLUSIONS}

The atmospheric TSP was continuously collected at KUWAMS, a remote background site in western Japan, from November 2019 to April 2020, and nine PAHs in the TSP samples were analyzed. Due to its location in the East Asian monsoon zone, the air quality at KUWAMS is greatly affected by the transport of polluted air masses from northern China during the cold season. Compared with the previous 15 years of observations at KUWAMS, the average concentration of TSP and PAHs decreased significantly during this sampling period. Based on the concentration profile, the decrease in TSP and PAHs at KUWAMS before the COVID-19 outbreak was related to the implementation of stringent air pollution control measures in China. During the period of COVID-19 control, the widespread suspension of industrial and traffic activities in China resulted in a low level of TSP and PAHs at KUWAMS from late January to April. In particular, in the week overlapping with the Chinese Spring Festival (between January 25 and February 1), the PAH concentration at KUWAMS dropped to the lowest level of the cold seasons between 2015 and 2020. This can

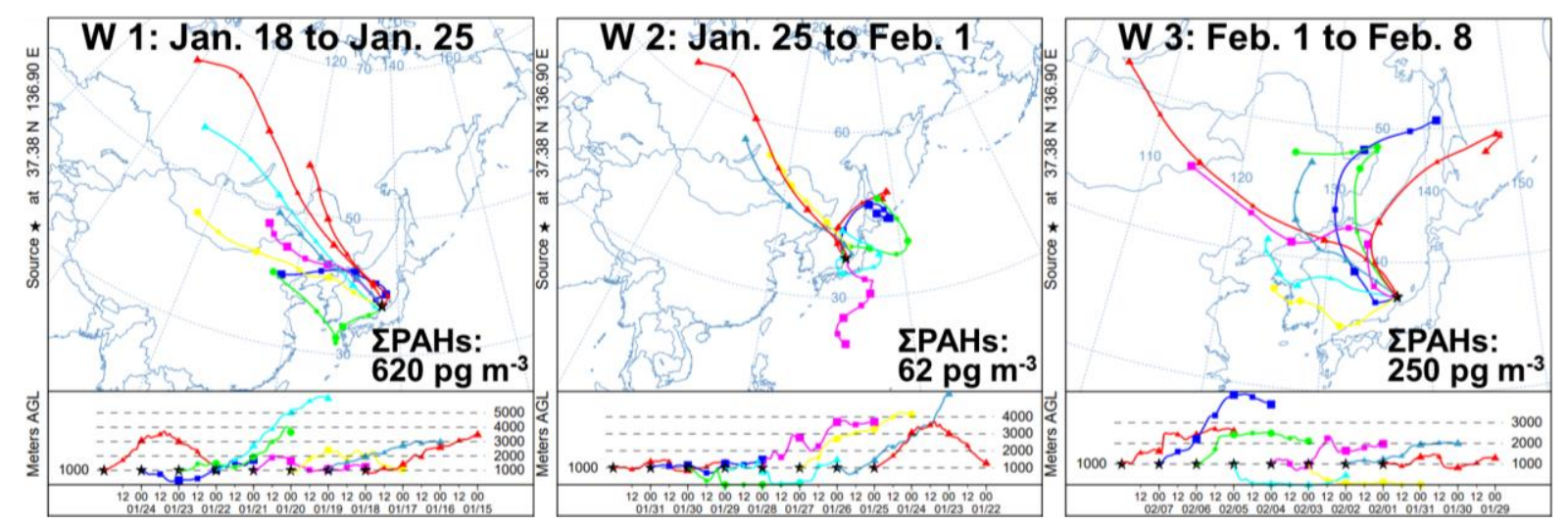

Fig. 4. Back trajectories at $1000 \mathrm{~m}$ above KUWAMS within the week before (W 1), during (W 2) and after (W 3) the Chinese Spring Festival using HYSPLIT-WEB model provided by the Air Resources Laboratory, NOAA. 


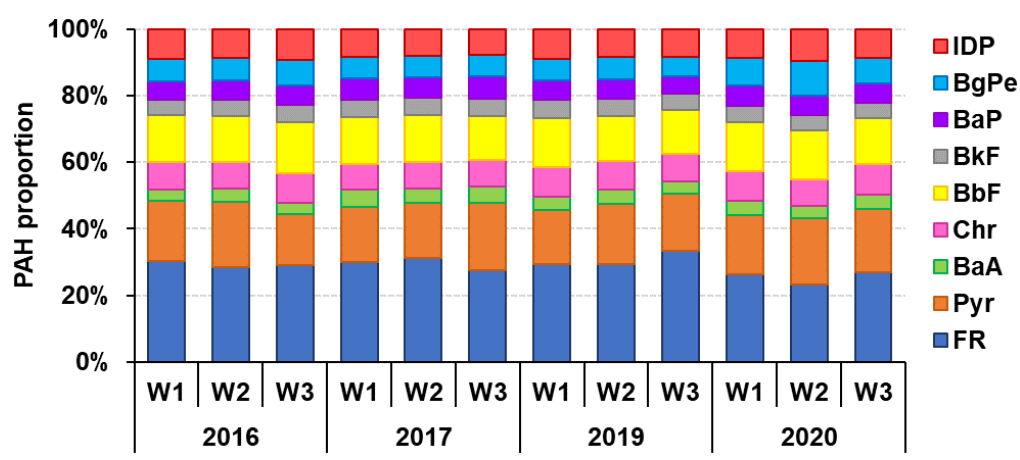

Fig. 5. Composition of PAHs at KUWAMS in W 1, W 2, and W 3 from 2016 to 2020. The data for 2016 to 2019 were collected from Zhang et al. (2020e). The data for 2018 were not available due to a sampler failure.

be attributed to the reduced intensity of emissions in China and the dilution with cleaner air. In addition, it was found that the composition of PAHs at KUWAMS remained stable because the emission sources did not change substantially. These results indicate that the characteristics of PAHs at KUWAMS directly reflect the air pollution control policies adopted in China. Moreover, the observations at KUWAMS during COVID-19 emphasize that a decline in anthropogenic emissions from the Chinese mainland would reduce the air pollutants involved in long-range transport and change the distribution of PAHs and other pollutants in the atmosphere over East Asia. Therefore, the Chinese government should continue its efforts to strictly control the emission of air pollutants, which will be beneficial to the improvement of air quality in China and in downwind areas.

\section{ACKNOWLEDGEMENT}

This work was supported by the Ministry of Education, Culture, Sports, Science and Technology, Japan (17K08388); the Sasakawa Scientific Research Grant from the Japan Science Society (2020-6003); the Environment Research and Technology Development Fund (5-1951) of the Environmental Restoration and Conservation Agency of Japan; the Sumitomo Foundation, Japan (183115); the CHOZEN Project of Kanazawa University, Japan; and the Institute of Nature and Environmental Technology, Kanazawa University, Japan (20015, 20016, 20017, 20018, 20019). The authors thank Mrs. Naoko Kato of Kanazawa University, Japan, for her assistance in analyzing the samples.

\section{REFERENCES}

Araki, Y., Tang, N., Ohno, M., Kameda, T., Toriba, A. and Hayakawa, K. (2009). Analysis if atmospheric polycyclic aromatic hydrocarbons and nitro polycyclic aromatic hydrocarbons in gas/particle phases separately collected by a high-volume air sampler equipped with a column packed with XAD-4 resin. J. Health Sci. 55: 77-85. https://doi.org/10.1248/jhs.55.77

Beijing Municipal Environmental Protection Bureau (BMEPB) (2008). Beijing environmental statement 2008. http://sthjj.beijing.gov.cn/bjhrb/resource/cms/2018/04/20 18042409503329302.pdf bp p.l.c. (2019). Statistical review of world energy 2019. https://www.bp.com/en/global/corporate/energy-econom ics/statistical-review-of-world-energy.html

Chang, S.S., Lee, W.J., Wang, L.C., Lin, N.H. and ChangChien, G.P. (2013). Influence of the Southeast Asian biomass burnings on the atmospheric persistent organic pollutants observed at near sources and receptor site. Atmos. Environ. 78: 184-194. https://doi.org/10.1016/j.a tmosenv.2012.07.074

Cheruiyot, N.K., Lee, W.J., Mwangi, J.K., Wang, L.C., Lin, N.H., Lin, Y.C., Cao, J., Zhang, R. and Chang-Chien, G.P. (2015). An overview: Polycyclic aromatic hydrocarbon emissions from the stationary and mobile sources and in the ambient air. Aerosol Air Qual. Res. 15: 2730-2762. https://doi.org/10.4209/aaqr.2015.11.0627

Daisey, J.M., Keyko, M.H. and Kneip, T.J. (1979). Source identification and allocation of polycyclic aromatic hydrocarbon compounds in the New York city aerosol: Methods and applications. In Polynuclear aromatic hydrocarbons. 3rd International symposium on chemistry and biology-carcinogenesis and mutagenesis, Jones, P.W. and Leber, P. (Eds.), Ann Arbor Science Publishers Inc., Ann Arbor, pp. 201-215.

Delhomme, O. and Millet, M. (2012). Characterization of particulate polycyclic aromatic hydrocarbons in the east of France urban areas. Environ. Sci. Pollut. Res. 19: 1791-1799. https://doi.org/10.1007/s11356-011-0701-3

Dickhut, R.M., Canuel, E.A., Gustafson, K.E., Liu, K., Arzayue, K.M., Walker, S.E., Edgecombe, G., Gaylor, M.O. and Macdonald, E.H. (2000). Automotive sources of carcinogenic polycyclic aromatic hydrocarbons associated with particulate matter in the Chesapeake Bay region. Environ. Sci. Technol. 34: 4635-4640. https://doi.org/10.1021/es000971e

Durant, J.L., Busby Jr, W.F., Lafleur, A.L., Penman, B.W. and Crespi, C.L. (1996). Human cell mutagenicity of oxygenated, nitrated and unsubstituted polycyclic aromatic hydrocarbons associated with urban aerosols. Mutat. Res. 371: 123-157. https://doi.org/10.1016/S0165-1218(96)9 0103-2

Hayakawa, K., Tang, N., Nagato, G., Toriba, A., Sakai, S., Kano, F., Goto, S., Endo, O., Arashidani, K. and Kakimoto, H. (2018). Long term trends in atmospheric concentrations of polycyclic aromatic hydrocarbons and 
nitropolycyclic aromatic hydrocarbons: A study of Japanese cities from 1997 to 2014. Environ. Pollut. 233: 474-482. https://doi.org/10.1016/j.envpol.2017.10.038

Hayakawa, K., Tang, N., Nagato, E., Toriba, A., Lin, J.-M., Zhao, L., Zhou, Z., Qing, W., Yang, X., Mishukov, V., Neroda, A. and Chung, H.Y. (2020). Long-term trends in urban atmospheric polycyclic aromatic hydrocarbons and nitropolycyclic aromatic hydrocarbons: China, Russia, and Korea from 1999 to 2014. Int. J. Environ. Res. Public Health 17: 431. https://doi.org/10.3390/ijerph17020431

Huang, B., Liu, M., Bi, X.H., Chaemfa, C., Ren, Z.F., Wang, X.M., Sheng, G.Y. and Fu, J.M. (2014). Phase distribution, sources and risk assessment of PAHs, NPAHs and OPAHs in a rural site of Pearl River Delta region, China. Atmos. Pollut. Res. 5: 210-218. https://doi.org/10.5094/A PR.2014.026

Huang, J., Pan, X., Guo, X. and Li, G. (2018). Health impact of China's air pollution prevention and control action plan: An analysis of national air quality monitoring and mortality data. Lancet Planet. Health 2: e313-e323. https://doi.org/10.1016/S2542-5196(18)30141-4

Huang, W., Huang, B., Bi, X.H., Lin, Q.H., Liu, M., Ren, Z.F., Zhang, G.H., Wang, X.M., Sheng, G.Y. and Fu, J.M. (2014). Emission of PAHs, NPAHs and OPAH from residential honeycomb coal briquette combustion. Energy Fuels 28: 636-642. https://doi.org/10.1021/ef401901d

Inomata, Y., Kajino, M., Sato, K., Kurokawa, J., Tang, N., Ohara, T., Hayakawa, K. and Ueda, H. (2017). Sourcereceptor relationship analysis of the atmospheric deposition of PAHs subject to long-range transport in northeast Asia. Environ. Sci. Technol. 51: 7972-7981. https://doi.org/10.1021/acs.est.7b00776

Japan Meteorological Agency (JMA) (2020). Observation date and points of Kosa (Asian dust) in 2020. https://www.data.jma.go.jp/gmd/env/kosahp/kosa_table_ 2020.html

Kishida, M., Nishikawa, A., Fujimori, K. and Shibutani, Y. (2011). Gas-particle concentrations of atmospheric polycyclic aromatic hydrocarbons at an urban and a residential site in Osaka, Japan: Effect of the formation of atmospherically stable layer on their temporal change. $J$. Hazard. Mater. 192: 1340-1349. https://doi.org/10.1016/ j.jhazmat.2011.06.046

Lee, W.J., Wang, Y.F., Lin, T.C., Chen, Y.Y., Lin, W.C., $\mathrm{Ku}$, C.C. and Cheng, J.T. (1995). PAH characteristics in the ambient air of traffic-source. Sci. Total Environ. 159: 185-200. https://doi.org/10.1016/0048-9697(95)04323-S

Lee, W.J., Liow, M.C., Tsai, P.J. and Hsieh, L.T. (2002). Emission of polycyclic aromatic hydrocarbons from medical waste incinerators. Atmos. Environ. 36: 781-790. https://doi.org/10.1016/S1352-2310(01)00533-7

Lee, W.J., Chao, W.H., Shih, M.L., Tsai, C.H., Chen, T.J.H. and Tsai, P.J. (2004). Emissions of polycyclic aromatic hydrocarbons from batch hot mix asphalt plants. Environ. Sci. Technol. 38: 5274-5280. https://doi.org/10.1021/es0 35455d

Li, P., Sato, K., Hasegawa, H., Huo, M., Minoura, H., Inomata, Y., Take, N., Yuba, A., Futami, M., Takahashi, T. and Kotake, Y. (2018). Chemical characteristics and source apportionment of $\mathrm{PM}_{2.5}$ and long-range transport from northeast Asia continent to Niigata in eastern Japan. Aerosol Air Qual. Res. 18: 938-956. https://doi.org/10.42 09/aaqr.2017.05.0181

Lin, C.C., Chen, S.J., Huang, K.L., Lee, W.J., Lin, W.Y., Tsai, J.H. and Chaung, H.C. (2008). PAHs, PAH-induced carcinogenic potency, and particle-extract-induced cytotoxicity of traffic-related nano/ultrafine particles. Environ. Sci. Technol. 42: 4229-4235. https://doi.org/10. 1021/es703107w

Liu, D., Xu, Y., Chaemfa, C., Tian, C.G., Li, J., Luo, C.L. and Zhang, G. (2014). Concentrations, seasonal variations, and outflow of atmospheric polycyclic aromatic hydrocarbons (PAHs) at Ningbo site, Eastern China. Atmos. Pollut. Res. 5: 203-209. https://doi.org/10.5094/A PR.2014.025

Masclet, P., Bresson, M.A. and Mouvier, G. (1987). Polycyclic aromatic hydrocarbons emitted by power stations and influence of combustion conditions. Fuel 66: 556-562. https://doi.org/10.1016/0016-2361(87)90163-3

Ministry of Ecology and Environment of the People's Republic of China (MEE) (2020a). Monthly report for national air quality. http://www.mee.gov.cn/hjzl/dqhj/cs kqzlzkyb/

Ministry of Ecology and Environment of the People's Republic of China (MEE) (2020b). Smog still a problem amid viral contagion. http://english.mee.gov.cn/News_se rvice/media_news/202002/t20200214_763873.shtml

Morisaki, H., Nakamura, S., Tang, N., Toriba, A. and Hayakwa, K. (2016). Benzo[c]fluorene in urban air: HPLC determination and mutagenic contribution relative to benzo[a]pyrene. Anal. Sci. 32: 233-236. https://doi.org/1 0.2116/analsci.32.233

National Bureau of Statistics of China (NBSC) (2019). China statistical yearbook 2019. http://www.stats.gov.cn/ tjsj/ndsj/2019/indexeh.htm

National Development and Reform Commission (NDRC) (2017). Notice on issuing the clean energy for winter heating in northern China (2017-2021). https://www.ndr c.gov.cn/xxgk/zcfb/tz/201712/t20171220_962623.html

Odabasi, M., Cetin, E. and Sofuoglu, A. (2006). Determination of octanol-air partition coefficients and supercooled liquid vapor pressures of PAHs as a function of temperature: Application to gas-particle partitioning in an urban atmosphere. Atmos. Environ. 40: 6615-6625. https://doi.org/10.1016/j.atmosenv.2006.05.051

Ohura, T., Amagai, T., Fusaya, M. and Matsushita, H. (2004). Spatial distributions and profiles of atmospheric polycyclic aromatic hydrocarbons in two industrial cities in Japan. Environ. Sci. Technol. 38: 49-55. https://doi.org/ 10.1021/es030541z

Pan, X., Uno, I., Hara, Y., Kuribayashi, M., Kobayashi, H., Sugimoto, N., Yamamoto, S., Shimohara, T. and Wang, Z. (2015). Observation of the simultaneous transport of Asian mineral dust aerosols with anthropogenic pollutants using a POPC during a long-lasting dust event in late spring 2014. Geophys. Res. Lett. 42: 1593-1598. https://doi.org/10.1002/2014GL062491

Pankow, J.F. (1987). Review and comparative-analysis of 
the theories on partitioning between the gas and aerosol particulate phases in the atmosphere. Atmos. Environ. 21: 2275-2283. https://doi.org/10.1016/0004-6981(87)90363-5

Pankow, J.F. (1994). An absorption model of gas/particle partitioning of organic compounds in the atmosphere. Atmos. Environ. 28: 185-188. https://doi.org/10.1016/13 52-2310(94)90093-0

Pankow, J.F. (1998). Further discussion of the octanol/air partition coefficient $\mathrm{K}_{\mathrm{oa}}$ as a correlating parameter for gas/particle partitioning coefficients. Atmos. Environ. 32: 1493-1497. https://doi.org/10.1016/S1352-2310(97)00383-X

Phoungthong, K., Tekasakul, S., Tekasakul, P. and Furuuchi, M. (2017). Comparison of particulate matter and polycyclic aromatic hydrocarbons in emissions from IDI-turbo diesel engine fueled by palm oil-diesel blends during long-term usage. Atmos. Pollut. Res. 8: 344-350. https://doi.org/10.1016/j.apr.2016.10.006

Ravindra, K., Sokhi, R. and Grieken, R.V. (2008). Atmospheric polycyclic aromatic hydrocarbons: Source attribution, emission factors and regulation. Atmos. Environ. 42: 2895-2921. https://doi.org/10.1016/j.atmos env.2007.12.010

Rogge, W.F., Hildemann, L.M., Mazurek, M.A., Cass, G.R. and Simoneit, B.R.T. (1993). Sources of fine organic aerosol. 2. Noncatalyst and catalyst-equipped automobiles and heavy-duty diesel trucks. Environ. Sci. Technol. 27: 636-651. https://doi.org/10.1021/es00041a007

Salthammer, T. and Schripp, T. (2015). Application of the Junge- and Pankow-equation for estimating indoor gas/particle distribution and exposure to SVOCs. Atmos. Environ. 106: 467-476. https://doi.org/10.1016/j.atmosen v.2014.09.050

Sanderson, E.G., Raqbi, A., Vyskocil, A. and Farant. J.P. (2004). Comparison of particulate polycyclic aromatic hydrocarbon profiles in different regions of Canada. Atmos. Environ. 38: 3417-3429. https://doi.org/10.1016/ j.atmosenv.2004.03.026

Shen, H., Huang, Y., Wang, R., Zhu, D., Li, W., Shen, G., Wang, B., Zhang, Y., Chen, Y., Lu, Y., Chen, H., Li, T., Sun, K., Li, B., Liu, W., Liu, J. and Tao, S. (2013). Global atmospheric emissions of polycyclic aromatic hydrocarbons from 1960 to 2008 and future predictions. Environ. Sci. Technol. 47: 6415-6424. https://doi.org/10.1021/es400857z

Sheu, H.L., Lee, W.J., Tsai, J.H., Fan, Y.C., Su, C.C. and Chao, H.R. (1996). Particle size distribution of polycyclic aromatic hydrocarbons in the ambient air of a traffic intersection. J. Environ. Sci. Health A 31: 1293-1316. https://doi.org/10.1080/10934529609376425

Sheu, H.L., Lee, W.J., Lin, S.J., Fang, G.C., Chang, H.C. and You, W.C. (1997). Particle-bound PAH content in ambient air. Environ. Pollut. 96: 369-382. https://doi.org/10.1016/S0269-7491(97)00044-4

Sicre, M.A., Marty, J.C., Saliot, A., Aparicio, X., Grimalt, J. and Albaiges, J. (1987). Aliphatic and aromatic hydrocarbons in different sized aerosols over the Mediterranean Sea: Occurrence and origin. Atmos. Environ. 21: 2247-2259. https://doi.org/10.1016/00046981(87)90356-8

Simcik, M.F., Eisenreich, S.J. and Lioy, P.J. (1999). Source apportionment and source/sink relationships of PAHs in the coastal atmosphere of Chicago and Lake Michigan. Atmos. Environ. 33: 5071-5079. https://doi.org/10.1016/ S1352-2310(99)00233-2

State Council of the People's Republic of China (2013). Notice of the general office of the state council on issuing the air pollution prevention and control action plan. http://www.gov.cn/zwgk/2013-09/12/content_2486773.htm

Sun, D, Fang, J. and Sun, J. (2018). Health-related benefits of air quality improvement from coal control in China: Evidence from the Jing-Jin-Ji region. Resour. Conserv. Recycl. 129: 416-423. https://doi.org/10.1016/j.resconrec. 2016.09.021

Tang, N., Hattori, T., Taga, R., Igarashi, K., Yang, X.Y., Tamura, K., Kakimoto, H., Mishukov, V.F., Toriba, A., Kizu, R. and Hayakawa, K. (2005). Polycyclic aromatic hydrocarbons and nitropolycyclic aromatic hydrocarbons in urban air particulates and their relationship to emission sources in the Pan-Japan Sea countries. Atmos. Environ. 39: 5817-5826. https://doi.org/10.1016/j.atmosenv.2005. 06.018

Tang, N., Izzaki, A., Tokuda, T., Ji, R.N., Dong, L.J., Wu, Q., Zhou, Z.J., Huang, R., Lin, Z.Y., Kameda, T., Toriba, A., Shima, M. and Hayakawa, K. (2013). Characteristics of atmospheric polycyclic aromatic hydrocarbons in Shenyang, Shanghai and Fuzhou, China. BUNSEKI KAGAKU 62: 267-273. https://doi.org/10.2116/bunsekikagaku.62.267

Tang, N., Sato, K., Tokuda, T., Tatematsu, M., Hama, H., Suematsu, C., Kameda, T., Toriba, A. and Hayakawa, K. (2014). Factors affecting atmospheric 1-, 2-nitropyrenes and 2-nitrofluoranthene in winter at Noto peninsula, a remote background site, Japan. Chemosphere 107: 324330. https://doi.org/10.1016/j.chemosphere.2013.12.077

Tang, N., Hakamata, M., Sato, K., Okada, Y., Yang, X., Tatematsu, M., Toriba, A., Kameda, T. and Hayakawa, K. (2015). Atmospheric behaviors of polycyclic aromatic hydrocarbons at a Japanese remote background site, Noto peninsula, from 2004 to 2014. Atmos. Environ. 120: 144 151. https://doi.org/10.1016/j.atmosenv.2015.08.090

Tang, N., Suzuki, G., Morisaki, H., Tokuda, T., Yang, X.Y., Zhao, L.X., Lin, J., Kameda, T., Toriba, A. and Hayakawa, K. (2017). Atmospheric behaviors of particulate-bound polycyclic aromatic hydrocarbons and nitropolycyclic aromatic hydrocarbons in Beijing, China from 2004 to 2010. Atmos. Environ. 152: 354-361. https://doi.org/10.1016/j.atmosenv.2016.12.056

Tang, S., Zhou, X., Zhang, J., Xue, L., Luo, Y., Song, J. and Wang, W. (2020). Characteristics of water-soluble organic acids in $\mathrm{PM}_{2.5}$ during haze and Chinese Spring Festival in winter of Jinan, China: Concentrations, formations, and source apportionments. Environ. Sci. Pollut. Res. 27: 1212212137. https://doi.org/10.1007/s11356-020-07714-7

Xing, W.L., Zhang, L.L., Yang, L., Zhou, Q.Y., Zhang, X., Toriba, A., Hayakawa, K. and Tang, N. (2020). Characteristics of $\mathrm{PM}_{2.5}$-bound polycyclic aromatic hydrocarbons and nitro-polycyclic aromatic hydrocarbons at a roadside air pollution monitoring station in Kanazawa, Japan. Int. J. Environ. Res. Public. Health 17: 805. https://doi.org/10.3390/ijerph17030805 
Xu, K., Cui, K., Young, L.H., Hsieh, Y.K., Wang, Y.F., Zhang, J. and Wan, S. (2020). Impact of the COVID-19 event on air quality in central China. Aerosol Air Qual. Res. 20: 915-929. https://doi.org/10.4209/aaqr.2020.04.0150

Yamasaki, H., Kuwata, K. and Miyamoto, H. (1982). Effects of temperature on aspects of airborne polycyclic aromatic hydrocarbons. Environ. Sci. Technol. 16: 189-194. https://doi.org/10.1021/es00098a003

Yang, H.H., Lee, W.J., Chen, S.J. and Lai, S.O. (1998). PAH emission from various industrial stacks. J. Hazard. Mater. 60: 159-174. https://doi.org/10.1016/S0304-3894(98)00 089-2

Yang, L., Suzuki, G., Zhang, L.L., Zhou, Q.Y., Zhang, X., Xing, W.L., Shima, M., Yoda, Y., Nakatsubo, R., Hiraki, T., Sun, B.J., Fu, W.H., Qi, H.Y., Hayakawa, K., Toriba, A. and Tang, N. (2019). The characteristics of polycyclic aromatic hydrocarbons in different emission source areas in Shenyang, China. Int. J. Environ. Res. Public. Health 16: 2817. https://doi.org/10.3390/ijerph16162817

Yang, X.Y., Okada, Y., Tang, N., Matsunaga, S., Tamura, K., Lin, J.M., Kameda, T., Toriba, A. and Hayakawa, K. (2007). Long-range transport of polycyclic aromatic hydrocarbons from China to Japan. Atmos. Environ. 41: 2710-2718. https://doi.org/10.1016/j.atmosenv.2006.11.052

Zhang, L.L., Morisaki, H., Wei, Y.J., Li, Z., Yang, L., Zhou, Q.Y., Zhang, X., Xing, W.L., Hu, M., Shima, M., Toriba, A., Hayakawa, K. and Tang, N. (2019a). Characteristics of air pollutants inside and outside a primary school classroom in Beijing and respiratory health impact on children. Environ. Pollut. 255: 113147. https://doi.org/10. 1016/j.envpol.2019.113147

Zhang, L.L., Tokuda, T., Yang, L., Zhou, Q., Zhang, X.Y., Xing, W.L., Wu, Q., Zhou, Z.J., Chen, R., Kameda, T., Toriba, A., Hayakawa, K. and Tang, N. (2019b). Characteristics and health risks of particulate polycyclic aromatic hydrocarbons and nitro-polycyclic aromatic hydrocarbons at urban and suburban elementary schools in Shanghai, China. Asian J. Atmos. Environ. 13: 266275. https://doi.org/10.5572/ajae.2019.13.4.266

Zhang, L.L., Morisaki, H., Wei, Y.J., Li, Z.G., Yang, L., Zhou, Q.Y., Zhang, X., Xing, W.L., Hu, M., Shima, M., Toriba, A., Hayakawa, K. and Tang, N. (2020a). PM 2.5 -bound polycyclic aromatic hydrocarbons and nitro-polycyclic aromatic hydrocarbons inside and outside a primary school classroom in Beijing: Concentration, composition, and inhalation cancer risk. Sci. Total Environ. 705: 135840. https://doi.org/10.1016/j.scitotenv.2019.135840

Zhang, L.L., Yang, L., Zhou, Q.Y., Zhang, X., Xing, W.L., Wei, Y.J., Hu, M., Zhao, L.X., Toriba, A., Hayakawa, K. and Tang, N. (2020b). Size distribution of particulate polycyclic aromatic hydrocarbons in fresh combustion smoke and ambient air: A review. J. Environ. Sci. 88: 370-384. https://doi.org/10.1016/j.jes.2019.09.007
Zhang, L.L., Zhang, X., Xing, W.L., Zhou, Q.Y., Yang, L., Nakatsubo, R., Wei, Y.J., Bi, J.R., Shima, M., Toriba, A., Hayakawa, K. and Tang, N. (2020c). Natural aeolian dust particles have no substantial effect on atmospheric polycyclic aromatic hydrocarbons (PAHs): A laboratory study based on naphthalene. Environ. Pollut. 263: 114454. https://doi.org/10.1016/j.envpol.2020.114454

Zhang, Q., Zheng, Y., Tong, D., Shao, M., Wang, S., Zhang, Y., Xu, X., Wang, J., He, H., Liu, W., Ding, Y., Lei, Y., Li, J., Wang, Z., Zhang, X., Wang, Y., Cheng, J., Liu, Y., Shi, Q., ... Hao, J. (2019c). Drivers of improved PM $_{2.5}$ air quality in China from 2013 to 2017. Proc. Natl. Acad. Sci. USA 116: 24463-24469. https://doi.org/10.1073/pnas.19 07956116

Zhang, R., Zhang, Y., Lin, H., Feng, X., Fu, T.M. and Wang, Y. (2020d). $\mathrm{NO}_{\mathrm{x}}$ emission reduction and recovery during COVID-19 in east China. Atmosphere 11: 433. https://doi.org/10.3390/atmos 11040433

Zhang, X., Zhang, L.L., Yang, L., Zhou, Q.Y., Xing, W.L., Toriba, A., Hayakawa, K., Wei, Y.J. and Tang, N. (2020e). Characteristics of polycyclic aromatic hydrocarbons (PAHs) and common air pollutants at Wajima, a remote background site in Japan. Int. J. Environ. Res. Public. Health 17: 957. https://doi.org/10.3390/ijerph17030957

Zhang, X.Y., Wang, J.Z., Wang, Y.Q., Liu, H.L., Sun, J.Y. and Zhang, Y.M. (2015). Changes in chemical components of aerosol particles in different haze regions in china from 2006 to 2013 and contribution of meteorological factors. Atmos. Chem. Phys. 15: 12935-12952. https://doi.org/10. 5194/acp-15-12935-2015

Zhang, Y., Dong, S., Wang, H., Tao, S. and Kiyama, R. (2016). Biological impact of environmental polycyclic aromatic hydrocarbons (ePAHs) as endocrine disruptors. Environ. Pollut. 213: 809-824. https://doi.org/10.1016/j. envpol.2016.03.050

Zheng, B., Tong, D., Li, M., Liu, F., Hong, C., Geng, G., Li, H., Li, X., Peng, L., Qi, J., Yan, L., Zhang, Y., Zhao, H., Zheng, Y., He, K. and Zhang, Q. (2018). Trends in China's anthropogenic emissions since 2010 as the consequence of clean air actions. Atmos. Chem. Phys. 18: 1409514111. https://doi.org/10.5194/acp-18-14095-2018

Zhong, J., Zhang, X., Dong, Y., Wang, Y., Liu, C., Wang, J., Zhang, Y. and Che, H. (2018). Feedback effects of boundary-layer meteorological factors on cumulative explosive growth of $\mathrm{PM}_{2.5}$ during winter heavy pollution episodes in Beijing from 2013 to 2016. Atmos. Chem. Phys. 18: 247-258. https://doi.org/10.5194/acp-18-247-2018

Received for review, July 10, 2020

Revised, August 26, 2020 Accepted, August 27, 2020 